\title{
Inter-relationship between intrauterine dentistry and dentistry for babies: a literature review
}

\author{
João Augusto Cazuza ${ }^{\mathrm{a}}$, Karine Takahashi ${ }^{\mathrm{a}}$
}

\begin{abstract}
INTRODUCTION: Currently, intrauterine dentistry is a highly relevant topic, as its preventive measures can avoid several diseases, such as dental caries. Pregnancy is the ideal time for preventive and educational health measures to be put into practice, since future mothers are more receptive to changes and avid for knowledges that ensure the well-being of their baby.

OBJECTIVE: The aim of this work is to carry out a systematized review in a database regarding the interrelationship between the oral health care of the pregnant women and the development of healthy habits for babies.

METHODS: An exploratory bibliographic research was performed in books and databases through an online search in the literature. It was carried out a non-systematic review in the period between 1981 and 2015, in which the databases were LILACS, SciELO, MEDLINE, PUBMED and the Brazilian Digital Library of Theses and Dissertations (BDTD), using as descriptors: intrauterine dentistry; dentistry for babies; dental cavity; prevention; infants; prenatal dentistry; behavior; habits; pregnant women. It was also consulted textbooks and periodicals available in the library at Campus I of University of Western São Paulo.

CONCLUSION: It was concluded that dental care for pregnant woman is important for the development of good habits in children, where the level of mothers' knowledge about oral health will influence the prevalence of caries in their children.
\end{abstract}

Keywords: intrauterine pregnant women; dental caries/prevention \& control; child; preschool; oral hygiene.

\section{Inter-relação entre odontologia intrauterina e odontologia para bebês: uma revisão de literatura}

\section{RESUMO}

INTRODUÇÃO: A odontologia intrauterina é um tema altamente relevante do nosso tempo, pois suas medidas preventivas podem evitar várias doenças, como a cárie dentária. A gravidez é o período ideal para que sejam colocadas em prática medidas preventivas e educativas em saúde, uma vez que as futuras mães se encontram mais receptivas às mudanças, estando ávidas de conhecimento que assegurem o bem-estar de seu bebê.

OBJETIVO: Realizar uma revisão sistematizada em base de dados a respeito da inter-relação entre os cuidados de saúde bucal da gestante e o desenvolvimento de hábitos saudáveis para o bebê.

METODOLOGIA: Foi realizada uma pesquisa bibliográfica exploratória em livros e bases de dados com uma busca online na literatura. Executamos uma revisão não sistemática no período compreendido entre 1981 a 2015, em que as bases de dados foram LILACS, SCIELO, MEDLINE, PUBMED e a Biblioteca Digital Brasileira de Teses e Dissertações (BDTD), utilizando como descritores: odontologia intrauterina; odontologia para bebês; cárie dentária: prevenção; infantes: pré-natal odontológico; comportamento; hábitos; gestantes. Também foram consultados livros-textos e periódicos disponíveis na biblioteca do campus I da Universidade do Oeste Paulista. CONCLUSÃO: Conclui-se que os cuidados odontológicos com a gestante são importantes para que se desenvolvam bons hábitos na criança, em que os níveis de conhecimento em saúde bucal das mães vão influenciar na prevalência de cárie dos filhos.

Palavras-chave: gestantes; cárie dentária/prevenção \& controle; pré-escolar; higiene bucal. a University of West Sao Paulo, Presidente Prudente Sao Paulo, Brazil

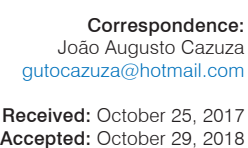

Accepted: October 29,2018

Conflict of Interests: The authors state that there re no financial and personal conflicts of interest that could have inappropriately influenced their work.

Copyright: @ 2018 Cazuza \& Takahashi licensee EDIPUCRS.

This work is licensed under a Creative Commons Attribution 4.0 International License. 


\section{INTRODUCTION}

Intrauterine dentistry is a highly relevant topic of our time, since its preventive measures can avoid several diseases, such as dental caries [1]. Furthermore, pregnancy is a favorable period for health promotion, not only through systematic clinical follow-up performed during prenatal care, but also through the possibility of establishment, incorporation and change of habits, as the singularity of the moment refers to a series of doubts, which may act as a stimulus for the pregnant woman to seek information and thus acquire new and better health practices [2]. Thus, at this moment, preventive and educational health measures should be put into practice, since future mothers are more receptive to the changes, being avid for knowledge in order to ensure the well-being of their baby. At no other time in their lives the parents will be as open to information as during the prenatal period [3].

An ideal model of treatment for pregnant women should include integrated and multiprofessional treatment, in which general and pediatric dentists, gynecologists, obstetricians, pediatricians and nutritionists work together with the patient. Simple measures, such as diet instruction, can lead to satisfactory results, since prevention is always the best form of any therapeutic approach to the disease [4]. It is important to notice that parents are the first agents of socialization, therefore, they promote or should promote the basic principles of hygiene and oral prevention in children, as well as a good perception about oral health attitudes, habits, behaviors and knowledge, which leads to the creation of concerns and follow-up of habits and oral health behaviors in their children [5].

Bearing that in mind, pediatric dentistry has established new paths in the search for oral health promotion through information on intrauterine dentistry and infants care [6]. Due to the importance of the oral health care of young children, it is recommended that the attention to this clientele should begin since their intrauterine life [7].

It is well known that in the prenatal period, quality care is essential to reduce the high rates of maternal and perinatal mortality in Brazil [8]. Therefore, health promotion should begin even before the infant curative care, since the ratio of age/probability of prevention in the first year of life is $96,5 \%$ and, after 12 months, it is $71,5 \%$, being evident the great importance of this period for oral health [9]. Furthermore, patterns of behavior learned during the earliest stages of human development are deeply rooted and resistant to change [11], for this reason, it is clear that preventive measures should be adopted in the earliest stages of life [12].

Through the exposed and based on a review of specialized literature, which shows that the concepts of dentistry for infants have been settling through last years.

\section{LITERATURE REVIEW}

An exploratory bibliographic research was carried out in books and databases through an online search in the literature.
A non-systematic review was performed in the period between 1981 and 2015, using the following descriptors: intrauterine dentistry; dentistry for babies; dental cavity; prevention; infants; prenatal dentistry; behavior; habits; pregnant women.

\section{Dental care for pregnant women}

Finkler et al. (2004) [15] observed that there is still a lack of preparation of the dentistry professional to deal with pregnant patients, as the fear of these professionals was mainly directed to the concerns regarding the curative treatments. Therefore, there should be an engagement among health professionals, including the dentist, who should be present at pregnant women prenatal care and, besides, a bond between the dentist and the pregnant woman should be created, so, in the future, dentist, pregnant woman and child will be walking together forming a health circle and thus benefit the whole family.

Leal and Jannotti (2009) [16] showed in their study that the pregnant woman oral health has been little approached in the health policies directed to this population group. They concluded that there is a culture that neither values nor stimulates the dental care during pregnancy.

Soares et al. (2009) [17] discussed the inclusion of highrisk pregnant women in prenatal dentistry. They emphasized the idea of multidisciplinarity as an adjuvant for the breaking of myths that are rooted in the population and in the medical and dental classes.

Reis et al. (2010) [18] explained that gestation is the moment in which the woman is more receptive to the changes and adhesion of information that can be applied for the benefit of their baby. Obtaining healthy habits and choices directly implies in a change in behavior.

Garbin et al. (2011) [19] analyzed the perceptions and attitudes about the pregnant women's oral health enrolled in the Pre-Natal SIS of the city of Bilac-SP. $80 \%$ did not receive any information about oral health during pregnancy, $60 \%$ did not seek dental surgeon during pregnancy, $45 \%$ did not know how to maintain the oral health of their babies and $85 \%$ were unaware of the meaning of caries disease. They concluded that the mothers had little knowledge regarding the preventive procedures in dentistry and on the diseases that can affect their oral health, as well as that of their babies.

\section{Mothers knowledge and perception}

Politano et al. (2004) [20] evaluated information given by mothers about oral care with babies, which, as a result, $33.33 \%$ of the mothers who were interviewed did not know how to tell when to initiate the oral hygiene of their child, 14 (33 33\%) of the interviewed mothers said that the best time to start the hygiene of the baby would be after birth, whereas for $11(26.19 \%)$ of these mothers, the best time would be after the eruption of the babies first tooth. Regarding the method used for the babies' oral hygiene, 19 mothers $(45.24 \%)$ reported having no knowledge at all, 10 mothers $(23.80 \%)$ thought that the cleaning should be done with water-based gauze or swab and 3 mothers $(7,14 \%)$ 
thought that the best option would be brushing with dental brush and 7 mothers $(16,66 \%)$ said that the important would be brushing with dental brush and sodium bicarbonate plus toothpaste. Likewise, when asked how hygiene should be done, $45.24 \%$ did not know how to respond.

Alves and Bezerra (2005) [21] understood that integral care to pregnant women during prenatal care constitutes, mainly in the Family Health Strategy (FHS), an extremely important factor for health professionals, because when the woman is assisted and cared for, there is the possibility of a quieter pregnancy and healthier babies. They concluded that only $38.88 \%$ of the interviewed women who sought FHS believe that dental treatment can cause harm to their baby and $58.34 \%$ of them received no guidance during the prenatal assistance about the oral health of their children.

Robles (2005) [22] observed in his studies that the hygiene guidelines for mothers were initiated late due to financial conditions. In some cases, the hygiene was reported to occur only after over six years old, and it was not considered a serious thing in that time, since there were no dentist visitations and dental appointments were only made in extreme cases.

Batistella et al. (2006) [5] verified that pediatric dentistry has been establishing new paths in the search for health promotion, making it clear that the awareness and the treatment of mothers in the prenatal period is important for prevention and effective control of oral diseases in their children.

Moura et al. (2007) [23] studied oral health knowledges and practices of mothers who attended a dental program for maternal and child care, verifying that the Preventive Program for Pregnant Women and Babies (PPPWB) is an extension program linked to the Federal University of Piauí (UFPI) which goal is to raise the awareness of pregnant women and mothers of children from 0 to 36 months old to perform habits that favor their health. In this work, a random selection of files of children who had participated in the PPPWB was carried out and, through these files, some letters were sent to their mothers. There was a return of 281 mothers, who were submitted to interviews involving topics covered by the Preventive Program for Pregnant Women and Babies. They concluded that the mothers who attended the program had a good level of information and adopted in their family context favorable health practices to control and prevention of oral diseases.

Granville-Garcia et al. (2007) [24] studied the pregnant women knowledge about oral health in a public and private hospital in the city of Caruaru-PE. The survey data were collected using standardized forms containing 12 questions. Most of these women reported having no fear of performing dental treatment during pregnancy and, among those who responded, the fear would only be due to the harm that the baby could suffer in some way. Most of the pregnant women who use both public and private services said that they did not receive any information about dental treatment, and if they received any, the dental surgeon was the informant.
Besides, all of them reported that they would like to receive some guidance.

Codato et al. (2008) [25] verified that the search for routine care was made only by pregnant women users of the SUS as a continuation of treatments performed since childhood, including dental treatments, which shows that this demand is related to the opportunity of access. The need to search for dental care during gestation was not observed, which may be related to the lack of information, cultural aspects, fears and myths.

Rodrigues (2008) [4] studied a sample composed of 94 parents or guardians and their respective children, where the responses were analyzed and compared, evaluating habits, knowledge and behaviors of the children reported. Results showed that the parents or guardians of these children mostly seem to have adequate behaviors, habits and oral health knowledge, as the parents are the first agents of socialization and they are the ones who promote the basic principles of hygiene and prevention in the children, consequently affecting their oral health.

Siqueira et al. (2009) [26] evaluated the interest of the parents in their children oral health through the attendance index of dental appointments, concerning preschool children aged 4 to 5 years, referred to a Basic Health Unit near to their homes. Results indicated the absence of information from the parents about the importance and care with oral hygiene, mainly about the primary teeth.

Pizi et al. (2009) [27] assessed in their study the knowledge degree regarding the dental care of pregnant women and that of their babies. Of 50 pregnant women who participated in a semi-open questionnaire that was divided in three parts (socioeconomic characterization, care for the pregnant woman and care for the newborn), $16 \%$ were single and $76 \%$ were married, aged $16-46$ years, with a family income of 1 to 4 minimum wages. The results showed that $36 \%$ of them performed dental treatment during pregnancy and $76 \%$ believed that they could have receive treatment in pregnancy, $48 \%$ believed that the number of caries increased and $78 \%$ believed that they performed oral hygiene correctly. As for baby care, $4 \%$ believed that the primary teeth should not be taken care of as the permanent ones have to be, $30 \%$ use baby bottles and think they are correct, whereas all of them said that baby pacifiers use is bad and $46 \%$ of them had some information about baby hygiene. They concluded that pregnant women are being better informed about their own dental care and those of their babies, but clearly there are still doubts and the lack of application of this knowledge.

Robles et al. (2010) [28] aimed to know the oral health practices and its meanings for mothers of children attending pediatric dentistry clinics at the Federal University of Santa Catarina. The population that was studied consisted of seven mothers who used to take their children to dental care at the university. It was observed that negative experiences in previous dental treatments, financial difficulties and pregnancy influenced them in the search for treatments. However, the search for the dental care was mainly to curative treatments instead of preventive procedures. 
Bastiani et al. (2010) [29] found in a study about the knowledge of pregnant women regarding the oral alterations and dental treatment during pregnancy that the maintenance of health during pregnancy is extremely important, but not all the population has easy access to it, specially to the information about oral health. In this study, 80 pregnant women from private medical offices and from Basic Health Units of the city of Maringá-PR were interviewed, which the main results showed that only a small portion of them $(33 \%)$ received information about how to maintain their oral health.

Guiotoku and Guiotoku (2010) [30] analyzed the mothers who attend the Basic Health Unit in Vila Verde - Curitiba -PR regarding the oral hygiene of their babies. They verified the importance of health in child development, which is demonstrated by the systemic reflexes, where most diseases and parafunctional habits result during the growth of the child from zero to five years old. It is of paramount importance to emphasize the responsibility of the parents in promoting and maintaining the health of their children. Regarding the ideal moment to begin the oral hygiene of the baby, $79.2 \%$ of the women answered that it would be before the eruption of the first tooth. $77 \%$ of them reported already having received guidance on oral hygiene in infants and 70\% received guidance from the oral health team. $33 \%$ answered that the first consultation should be only when the first tooth erupt, on the other hand, $29 \%$ thought that it would be only when the babies show some pain.

Serpa and Freire (2012) [31] studied the perception of pregnant women from João Pessoa-PB about the oral health of their babies, where 80 pregnant women who belonged to 13 Health Units of the Health District III were interviewed. Results showed that $75 \%$ of the pregnant women did not receive any guidance on oral health, but most of them were well informed about the first dental appointment before the baby's first year of life, the harmful habits of non-nutritive sucking (85\%) and the importance of early oral hygiene $(86.3 \%)$. Indiscriminate nightly breastfeeding acts as a risk of developing carious lesions for $10 \%$ of this sample. The dental surgeon was responsible for $18.9 \%$ of the information given. Therefore, it is concluded that few pregnant women received some type of information or orientation to oral health during the prenatal period, However, the majority presented a certain level of knowledge regarding these factors.

\section{Intrauterine and pediatric dentistry}

Pellizzaro et al. (2008) [32] believe that the adequate breastfeeding time is of great importance, since early weaning can bring countless problems to the baby. Breastfeeding is considered one of the fundamental pillars for the promotion and protection of children's health, bringing benefits to the baby and assisting in its growth and development. Thus, it is concluded that natural breastfeeding is beneficial for both mother and child, since breast milk helps in growth and development.

Oliveira (2010) [33] understands that dentistry for babies consists of the dental care of children since their birth, in order to maintain oral health, where the role of the dentist is very important within the context of the child population's health. This work deals with the promotion of oral health in infants, showing the importance of early preventive care and the need for parents' guidance since the first months of their children's lives. Maternal information and knowledge about appropriate habits reflects on healthy attitudes regarding the oral health of their children.

Menezes and Couto (2011) [34] emphasize the reasons for early initiation of preventive procedures to improve the oral health of infants. Make parents aware of their role in hygiene and health promotion of their child is very important to obtain a population without caries or low incidence of them. The American Academy of Pediatric Dentistry recommends that the first oral examination should be done at the time of the first dental element eruption and not after the first year of life. On the other hand, intrauterine dentistry is a subject of high relevance, since the adoption of preventive measures in the intrauterine phase can prevent several diseases, among them, dental caries. The World Health Organization (WHO) recommends that, form the fourth month of the pregnancy on, women should avoid sugar intake so that the fetus does not develop an exaggerated attraction for these kinds of foods. It is necessary to perform a joint action between the dentistry and medicine sectors, providing better patient care, since, obviously, the buccal cavity can not be separated from the rest of the body.

Ferro et al. (2011) [35] affirm that the lack of access to dental care may be an obstacle in the care of the children's teething, where the doctor assumes an important role in the dissemination of preventive measures in oral health. They evaluated the knowledge and conduct of pediatricians about the children's oral health and, as a result, they observed that the knowledge of these professionals is still below expectations. According to the American Academy of Pediatrics, the pediatrician should be able to investigate whether the patient has a risk profile for developing caries by assessing habits such as nighttime breastfeeding, frequency and quality of hygiene, as well as behavioral eating habits. It is concluded that professionals with less time of career have more knowledge about oral health.

\section{DISCUSSION}

Nowadays, there is a great interest of the pregnant woman for the general health of her children and, consequently, with respect to the oral health of them. When mothers are convinced by dentists that healthy habits for her children should begin before their birth, at the first moment, they are astonished at such information, but soon they accept and adopt it, leading to highly positive tendencies. Studies are unanimous in demonstrating the positive role of these attitudes in the oral health of children, which remains until the adulthood.

Pizi et al. (2009) [27] affirm that pregnant women recognize that oral health care is extremely important, but they complain about the lack of access to information in the 
public system. According to Losso and Ramalho (2001) [36], many pregnant women seek dental care, but mainly for curative treatments. Dental care programs for pregnant women are really necessary, like a dental prenatal, and require multidisciplinary involvement.

Moura et al. (2007) [23] understand that an educational health program helps in the search to expand the existing and practiced knowledge by families or social groups and, through dialogues, seek for the construction of new learning, creating a social environment of development.

Losso and Ramalho (2001) [36], Bastiani et al. (2010) [29], Poletto et al. (2008) [37] and Serpa and Freire (2012) [31] emphasize that another quite controversial point in dentistry is regarding the prescription of fluorides in pregnant women. The current knowledge about the fluoride mechanism of action shows that its effect is predominantly topical, occurring mainly at the plaque-enamel interface, through remineralization of initial caries lesions and reduction of dental enamel solubility. However, the prescription of fluoridated medications in the prenatal period does not bring any benefit that justifies its indication. According to Lucisano et al. (2013) [38], prescription of fluorides by many gynecologists still occur.

According to Guiotoku and Guiotoku (2008) [30], studies prove the polarity of dental caries, and low-income mothers who have little access to information tend to have children who are more likely to develop early caries at childhood, leading to believe that the maternal profile greatly influences the baby's oral condition. For this reason, it is necessary to improve the quality of life and self-esteem of the low-income population, aiming a better acceptance and adherence of oral health information and their daily hygiene habits.

Batistella et al. (2006) [6] understand that if mothers had the habit of caring for their baby's teeth since birth and before the teeth's eruption, the children would probably be more receptive to oral hygiene, leading to positive habits for the rest of their lives.

According to Rodrigues (2008) [5], Moura et al. (2007) [23], Guiotoku and Guiotoku (2008) [30], Araújo et al. (2009) [39] and Silva et al. (2007) [40], dentistry goes from empiricism to scientific. The one that had essentially a curative role, today, has been changing this practice and focusing on prevention. Most of the authors consulted in our literature review agree that it is necessary to start the oral hygiene care of the child early.

Sheiham (2015) [41] emphasizes the importance of studying the influence of risk factors in the planning of future preventive strategies, in order to minimize the prevalence of caries and to respect the characteristics of the groups in question. The author affirms that preventive programs need risk factors control for dental caries, introducing guidelines of oral hygiene and diet. However, is still very complicated to achieve people's awareness, due to the fact that it does not depends only on the professionals, but also on the patient desire to change their attitudes and follow them.

Serpa and Freire (2012) [31] believe that for achieve the success of an oral health program, a good planning and monitoring of its organization is necessary in addition to periodic evaluations. Guidelines need constant reinforcement to be carried out properly. There were myths and beliefs that have led to a negative relationship between dentistry and gestation, which difficult the establishment of a new service for pregnant women. A good example to be cited is the myth that the pregnant woman can not be anesthetized to perform a dental treatment. For a long time, it was believed that the attention to the oral health of pregnant woman should be restricted only to the urgencies. Today, they also recommend limiting care only to the second trimester of pregnancy. It is of great importance the inclusion of dental care in the prenatal assistance, because with this bond formed still in this stage allows a continuity of the child oral care. The Ministry of Health recommends that when initiating prenatal care, the referral to the dental office and educational actions must occur. It is indicated that the children should have entry into the system from 6 months of age.

Gonzaga (2001) [4], in his study, explains that the WHO guides the importance in reducing sugar intake during gestation, which is one of the fundamental aspects for the prevention of caries disease. Dentists and gynecologistsobstetricians reported having instructed pregnant women to reduce their sugar intake between the 12th and 18th week of pregnancy, which is the period of embryonic development of the palate.

In the Basic Care Booklet no 17 of the Ministry of Health (2006) [42] it is emphasized that the condition in which the oral health of the pregnant woman is found during pregnancy has a great influence on the general and on the oral health of the baby. However, we must observe some situations, as for example, the need to consult the doctor when the use of anesthetics and medicines are necessary in a dental treatment; tetracycline should be avoided as it may cause pigmentation in the baby's teeth. Also, the pregnant woman presents a reduction of the physiological capacity of their stomach and with this they start to eat foods in smaller quantities but with a higher frequency, and this can lead to a greater risk to dental caries. Teeth begin to form during the intrauterine life, the deciduous ones from the sixth week and the permanent ones from the fifth month. There are some factors that can cause problems in the babies' teeth such as the occurrence of infections, medications, nutritional deficiencies among others. The mother feeding will positively affect the formation of the babies' teeth if ingested adequate amounts of nutrients, remembering that the use of fluorides during prenatal care are not recommended as they are not effective.

Takahashi (2009) [43] points out that the prevalence of dental caries in infants tends to increase with the increase of erupted teeth, and factors such as poor hygiene and inadequate diet tend to aggravate the occurrence of this pathology.

For Cunha et al. (2003) [44], when one thinks in a preventive scale, the dentistry for babies and the intrauterine dentistry are inserted as its first steps. It is known that habits acquired in childhood tend to last until adulthood, therefore, the acquisition of good habits of hygiene and diet is essential 
for children who are free of dental caries and to the success of preventive programs.

\section{CONCLUSION}

From the literature review, it can be concluded that:

- Dental care for pregnant women is important for the development of good oral health habits for the child;

- The level of knowledge of mothers regarding oral health habits tends to influence the prevalence of dental caries in children.

\section{REFERENCES}

1. Konishi F, Lima PA. Odontologia intrauterina: a construção da saúde bucal antes do nascimento. Rev Bras Odontol 2002; 59(5):294-5.

2. Codato LAB, Nakama L, Junior LC, Higasali MS. Atenção odontológica à gestante: papel dos profissionais de saúde. Ciência \& Saúde Coletiva 2011;16(4):2297-301. https://doi.org/10.1590/S1413-81232011000400029

3. Silva MV, Martelli PJL. Promoção em saúde bucal para gestantes: revisão de literatura. Odont Clin Cientific 2009;8(3):219-24.

4. Gonzaga HFS, Buso L, Jorge MA, Gonzaga LHS. Indicadores de saúde bucal de gestantes vinculadas ao programa de pré-natal em duas unidades básicas de saúde em Porto Alegre/RS. Porto Alegre; 2001;12(2):139-42.

5. Rodrigues CMNB. Comportamentos, hábitos e conhecimentos de saúde oral das crianças: Percepção dos Pais/Encarregados de Educação. [tese]. Lisboa: Universidade Aberta; 2008

6. Batistella FID, Imparato JCP, Raggio DP, Carvalho AS. Conhecimento das gestantes sobre saúde bucal: na rede pública e em consultórios particulares. RGO 2006;54(1):67-73.

7. Garboza CS, Walter LRF. Estudo da prevalência de cárie numa população de 0 a 5 anos atendida precocemente pela Bebê-Clínica da Universidade Estadual de Londrina. Semina 1997;18:51-4. https://doi.org/10.5433/16790367.1997v18n1p51

8. Organização da assistência pré-natal. In: Assistência pré-natal: Manual Técnico. 3a ed. Brasília: Ministério da Saúde; 2000 p. 9-12.

9. Rossetini SMO, Moreira EJG. Não há prevenção sem educação. J Assoc Paul Cir Dent; 1997.

10. Walter LRF, Nakama L. Pacientes de alto índice de cárie x pacientes de alto risco: qual a conduta. Artes médicas; 1992. p. 251-8.

11. Blinkhorn AS. Preventing dental disease through health education. Dent Health London 1986;25:7-9.

12. Blinkhorn AS. Dental preventive advice for pregnant and nursing mothers: sociological implications. Int Dent J 1981;31(1):14-22

13. Steffensen JE. Dental preventive advice for pregnant and nursing mothers: sociological implications. J Public Health Dent 1990;50(6):358-69. https:// doi.org/10.1111/j.1752-7325.1990.tb02151.x

14. Griffen AL, Goepferd SJ. Preventive oral health care for the infant, child and adolescent. Pediatr Clin North Am 1991;38(5):1209-26. https://doi. org/10.1016/S0031-3955(16)38195-0

15. Finkler M, Oleiniski DMB, Ramos FRS. Saúde bucal materno-infantil: um estudo de representações sociais com gestantes. Texto Contexto Enferm 2004;13(3):360-8. https://doi.org/10.1590/S0104-07072004000300004

16. Leal NP, Jannotti CB. Saúde bucal da gestante atendida pelo SUS: práticas e representações de profissionais e pacientes. Femina 2009;37(8):413-21.

17 Soares MRPS, Dias AM, Machado WC, Chave MGAM, Chaves Filho HDM. Pré-natal odontológico: a inclusão do cirurgião-dentista nas equipes de pré-natal. Revista Interdisciplinar de Estudos Experimentais 2009;1(2): 53-7.

18. Reis DM, Pitta DR, Ferreira HMB, Jesus MCP, Moraes MEL, Soares MG Educação em saúde como estratégia de promoção de saúde bucal em gestantes. Ciência \& Saúde Coletiva 2010;15(1):269-76. https://doi. org/10.1590/S1413-81232010000100032

19. Garbin CAS, Sumida DH, Santos RR, Chehoud KA, Moimaz SAS. Saúde coletiva: promoção de saúde bucal na gravidez. Rev. Odontol UNESP $2011 ; 40(4): 161-5$

20. Politano GT, Pellegrinetti MB, Echeverria SR, Imparato JCP. Avaliação da informação das mães sobre cuidados bucais com o bebê. Rev Ibero Am Odontopediatr Odontol Bebê 2004;7(36):138-48.

21. Alves CS, Bezerra MM. Atenção odontológica no pré-natal: a percepção das gestantes do Bairro Padre Palhano, Sobral-CE. Sanare. 2005;6(1):61-8.
22. Robles ACC. Atitude e percepção sobre saúde bucal de mães de crianças atendidas na Clínica de Odontopediatria da UFSC. [tese]. Florianópolis: Clínica de Odontopediatria da UFSC: 2005

23. Moura LFAD, Moura MS, Toledo OA. Conhecimentos e práticas em saúde bucal de mães que frequentaram um programa odontológico de atenção materno-infantil. Ciência \& Saúde Coletiva 2007;12(4):1079-86. https:// doi.org/10.1590/S1413-81232007000400029

24. Ganville-Garcia AF, Leite AF, Smith LEA, Campos RVS, Menezes VA Conhecimento de gestantes sobre saúde bucal no município de CaruaruPE. Revista de Odontologia da UNESP 2007;36(3):243-9.

25. Codato LAB, Nakama L, Melchior R. Percepção de gestantes sobre atenção odontológica durante a gravidez. Ciência \& Saúde Coletiva 2008;13(3):1075-80. https://doi.org/10.1590/S1413-81232008000300030

26. Siqueira D, Barnabé AS, Barbosa de Deus R, Ferraz RRN. Avaliação do interesse dos pais pela saúde bucal de seus filhos pelo índice de comparecimento às consultas odontológicas de crianças em idade préescolar. Com Scientiae Saúde 2009;8(2):239-44. https://doi.org/10.5585/ conssaude.v8i2.1493

27. Pizi EG, Borges R, Fonini A. Avaliação do grau de conhecimento quanto aos cuidados odontológicos da gestante e do bebê. Colloquium Vitae 2009;01(1):58-64. https://doi.org/10.5747/cv.2009.v01.n1.v009

28. Robles ACC, Grosseman S, Bosco VL. Práticas e significados de saúde bucal: um estudo qualitativo com mães de crianças atendidas na Universidade Federal de Santa Catarina. Ciência \& Saúde Coletiva 2010;15(2):3271-81. https://doi.org/10.1590/S1413-81232010000800033

29. Bastiani C, Cota ALS, Provenzano MGA, Fracasso MLC, Honório HM, Rios D. Conhecimento das gestantes sobre alterações bucais e tratamento odontológico durante a gravidez. Odontol Clín Cient 2010;9(2):155-60.

30. Guiotoku CM, Guiotoku SK. Conhecimento e percepção de mães da unidade de saúde Vila Verde em Curitiba-PR em relação à higiene bucal de seus bebês. Revista Gestão \& Saúde 2010;1(2):27-36.

31. Serpa EM, Freire PLL. Percepção das gestantes de João Pessoa-PB sobre a saúde bucal de seus bebês. Odontol Clín Cient 2012;11(2):121-5.

32. Pellizzaro D, Cota ALS, Correa GO, Garbelini CCD. Aleitamento natural e sua relação com o Sistema Estomatognático. UNOPAR Cient 2008;10(2):63-8

33. Oliveira ALBM, Botta AC, Rosell FL. Promoção de saúde bucal em bebês. Revista de Odontologia da Universidade de São Paulo. 2010;22(3): 247-53.

34. Menezes CFD, Couto GBL. A importância dos conhecimentos dos médicos pediatras e obstetras sobre a promoção de saúde: uma revisão de literatura. Odontol Clín Cient 2011:425-30.

35. Ferro RL, Bonow MLM, Romano AR, Torriani DD. Integração entre pediatria e odontopediatria: uma abordagem transdisciplinar na saúde bucal infantil. Revista da AMRIGS 2011;55(1):31-6.

36. Losso EM, Ramalho GM. Avaliação de prescrição de suplementos de flúor pré-natal em Curitiba e Região Metropolitana. RBGO 2001;23(6):391-5 https://doi.org/10.1590/S0100-72032001000600008

37. Poletto VC, Stona P, Weber JBB, Fritscher AMG. Atendimento odontológico em gestantes: uma revisão da literatura. Red de Revistas Científicas da América Latina 2008:14(26):64-75

38. Lucisano MP, Rehder Neto FC, Queiroz AM, Rossi A, Nelson-Filho P. Suplemento sistêmico de fluoretos na gestação- indicar ou não indicar? Arquivo Brasileiro de Odontologia 2013;9(2):18-26.

39. Araújo SM, Pohlmann CS, Reis VG. Conhecimento e atitudes dos médicos ginecologistas/obstetras a respeito da saúde bucal da gestante. RFO 2009;14(3):190-6

40. Silva EL. Odontologia para bebês. Revista Paraense de Medicina 2007 21(4):53-7.

41. Sheiham A, James WPT. Diet and Dental Caries: The Pivotal Role of Free Sugars Reemphasized. Journal of Dental Research 2015. International \& American Associations for Dental Research 2015. 2015, August 18: Critical Reviews in Oral Biology \& Medicine: 1-7

42. Organização da atenção à saúde bucal por meio do ciclo de vida indivíduo: Atenção à gestante. In: Caderno de Atenção Básica, no 17. Brasília: Ministério da saúde; 2006. p. 64-7.

43. Takahashi K. Avaliação da microbiota bucal de mães e pares de crianças aos 6, 12, 18 e 24 meses de idade e sua relação com dieta alimentar, hábitos de higiene bucal, condição gengival, erupção dentária e prevalência de cárie dentária. [tese]. Araçatuba: Faculdade de Odontologia da UNESP; 2009

44. Cunha RF, Delbem AC, Percinoto C, Saito TE. Dentistry for babies: a preventive protocol. ASDC J Dent Child 2000;67(2):89-92. 